\title{
Sir Sydney Sunderland and the Sunderland Society
}

\author{
Mario Gilberto Siqueira, MD, PhD, ${ }^{1}$ and David Gellinger Kline, MD ${ }^{2,3}$ \\ ${ }^{1}$ Peripheral Nerve Surgery Unit, Department of Neurosurgery, University of São Paulo Medical School, São Paulo, Brazil; \\ ${ }^{2}$ Department of Neurosurgery, Louisiana State University Health Sciences Center; and ${ }^{3}$ Department of Neurosurgery, Ochsner \\ Clinic, New Orleans, Louisiana
}

In this historical vignette the relevant aspects of the life of the exceptional neuroscientist Sir Sydney Sunderland and of the foundation and development of the Sunderland Society are presented. The relationship of Sir Sydney with the Society is also emphasized.

https://thejns.org/doi/abs/10.3171/2017.7.JNS171110

KEY WORDS Sir Sydney Sunderland; Sunderland Society; history

$\mathrm{S}$ YDNEY Sunderland (Fig. 1) was born in Brisbane, Australia, on the last day of 1910 . He received his early education in that city and, in 1930, was awarded an open scholarship and started his studies in a science course at the University of Queensland. At the time that he completed that course in science, there was no comprehensive medical training program in Brisbane, so he subsequently began his medical studies at the University of Melbourne. He graduated as a top student in 1935, having received numerous awards while in the medical school. ${ }^{2}$

Quite early as a medical student, Sydney Sunderland was attracted to research. He initially was greatly influenced at first by the neurologist Leonard Cox (Fig. 2A) and then by the charismatic anatomist Frederic Wood Jones (Fig. 2B). Such was Sunderland's distinction as an undergraduate that, immediately upon graduation, he moved directly into the academic world, sidestepping his internship year. Frederic Wood Jones offered him a senior lectureship in anatomy (Fig. 3) and, at the same time, he was appointed as an assistant neurologist in Cox's clinic at the Alfred Hospital. At the same hospital he had the opportunity to work with Cox's brother-in-law, the surgeon Hugh Trumble (Fig. 4), who had set up Australia's first neurosurgical unit at the Alfred hospital. ${ }^{4}$ At that time, Sunderland wished to become a surgeon, and possibly a neurosurgeon. This dream appeared dashed, however, when an infection caused him to lose the 2 distal phalanges of his right index finger. Although he was ambidextrous, he realized that this loss rendered his surgical future uncertain. In a paper titled "Less than ten-surgeons with amputated fingers,"1 Brown wrote that, during a luncheon discussion at the 34th annual meeting of the American Society for Surgery of the
Hand, after noticing that Sunderland, the meeting's guest speaker, had a mutilated right hand, he approached him and queried about his loss. Sunderland replied, "Oh, it's nothing, I can do anything with my hand ... the long finger has taken over the functions of the lost index finger as well as retaining its own, and the hand has lost none of its dexterity." Although much of the reparative nerve surgery on which Sunderland based his studies was performed by his mentor, Hugh Trumble, the latter was often assisted by Sunderland himself. Hugh Trumble, Sydney Sunderland, Leonard Cox, and Frederic Wood Jones all remained close colleagues and friends throughout their lives.

Sunderland's postgraduate activities from 1935 to 1937 provided the foundation for his future participation in neurological research. At the end of 1937 Frederic Wood Jones retired and, at that time, the previous occupant of a chairman's position exerted considerable influence over the appointment of his successor. There was only one man he had in mind. Consequently, in 1938, although still only 27 years of age, Sunderland was offered and accepted the Chair of Anatomy at the University of Melbourne. ${ }^{8} \mathrm{He}$ deferred initiating his professional duties there until 1940, so he could complete a number of trips and visits to other departments and laboratories around the world.

His first visit was to the Department of Anatomy in Oxford (Le Gros Clark), where he met the brilliant Pio del Rio-Hortega, a former student of the Nobel Laureate Ramon y Cajal. Rio-Hortega introduced Sunderland to the various silver staining techniques that the Spanish neurohistologists had developed for visualizing the fine structure of neurons and glial cells. ${ }^{2}$ While in Oxford, Sunderland also spent some time in the neurosurgical unit headed 


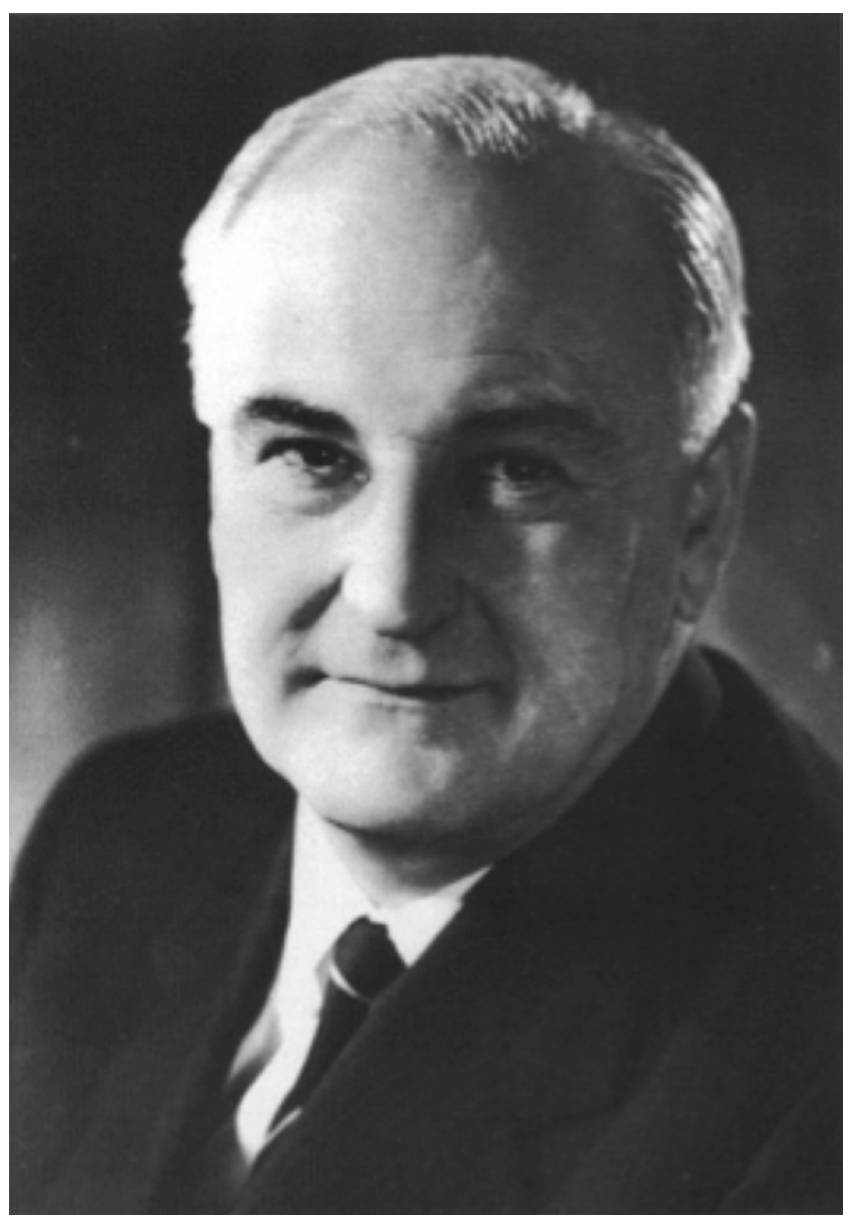

FIG. 1. Sir Sydney Sunderland (image courtesy of the School of Biomedical Sciences, University of Melbourne).

by Sir Hugh Cairns. In mid-1939, he went to the Montreal Neurological Institute to work with Wilder Penfield for a 3-month period, and then to neuroanatomical and clinical neurological groups in Toronto and at Harvard, as well as to work alongside the neurophysiologist John Fulton at Yale, the neurosurgeon Earl Walker at Johns Hopkins, and various other neurological centers in St. Louis, Chicago, Rochester, Los Angeles, and San Francisco. Sunderland returned to Melbourne at the end of 1939, just after the outbreak of the World War II, to find a university suffering from the constraints of a lack of funding and manpower. In addition to fulfilling his university commitments, he was immediately swept up in the war effort. ${ }^{2}$

During the war years, in addition to chairing the Department of Anatomy, Sunderland was in charge, with the rank of Honorary Major, of the Peripheral Nerve Injury Unit that had been established at the 115th Australian General Hospital in Heidelberg, Victoria. ${ }^{8}$ All Australian servicemen who sustained nerve injuries during World War II were referred to this unit for specialized treatment. There, Sunderland began his studies on nerve injuries, and the experience that he accumulated in this unit over the next 5 years was to provide the framework for his subsequent career. In 1945 he published an initial analysis of 301 cases of injury to peripheral nerves, and in 1947, a

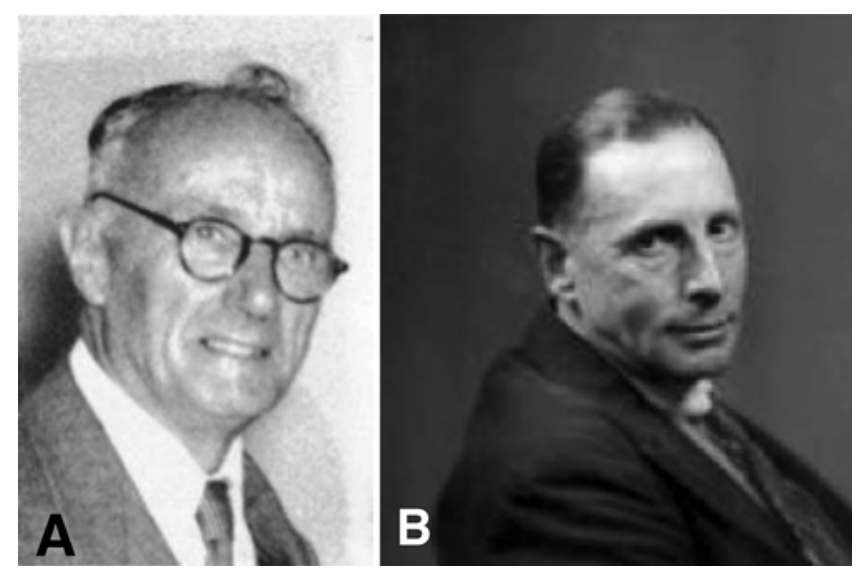

FIG. 2. A: Leonard Cox (image courtesy of The Royal Australasian College of Physicians). B: Frederic Wood Jones (image courtesy of the School of Biomedical Sciences, University of Melbourne).

review of 339 nerve injuries observed for periods of up to 6 years. At that time, he concluded that the results attained by adopting a more conservative approach to treatment were unexpectedly good, in that $68 \%$ of the patients across the entire series recovered spontaneously. After exploration, $17 \%$ were sutured, $1 \%$ grafted, and $1 \%$ freed from pressure of a cervical rib, whereas $6 \%$ experienced later spontaneous recovery, and $6 \%$ were found to be hopelessly damaged..$^{14}$

Sunderland enjoyed teaching and was an excellent lecturer. He never lectured from notes, and was a master of blackboard presentations. In the Old Anatomy School, he had 40 feet of blackboard space that he was known to completely fill in over the course of his lectures, all the while using different colors of chalk. ${ }^{8}$ He usually worked for long hours and kept a sofa bed at the university for the nights when it was too late to catch the tram home. ${ }^{5}$

In 1951, based on his already extensive experience with peripheral nerve injuries, Sunderland published his famous classification, ${ }^{10}$ which expanded Seddon's 3-tier grading system of traumatic nerve injuries ${ }^{9}$ into a 5-grade system by further separating neurotmetic injuries on the basis of finer anatomical distinctions. ${ }^{3}$ From then on, his fame spread and he was invited to meetings worldwide.

Following World War II, Sunderland returned to a wide range of medical, administrative, and governmental activities. He was elected dean of the Faculty of Medicine in 1953. During his 18 years as the dean, he held a parttime position as professor of anatomy. In 1961, he also was appointed professor of experimental neurology, and held this position, as well as that of dean of the School of Medicine in Melbourne, until 1971. He retired in 1975, but continued to work in the Department of Anatomy as an emeritus professor until 1993, the year of his death. During his deanship, he earned tremendous, universal respect and admiration. ${ }^{2}$ His unparalleled service to the medical school has since been recognized through the establishment of the Sunderland Prize in Neuroscience, awarded to medical students over the course of their training, and by the naming of the main lecture theater in the Medical Building as the Sunderland Theatre. ${ }^{8}$

Sunderland's scientific contributions were immense, 


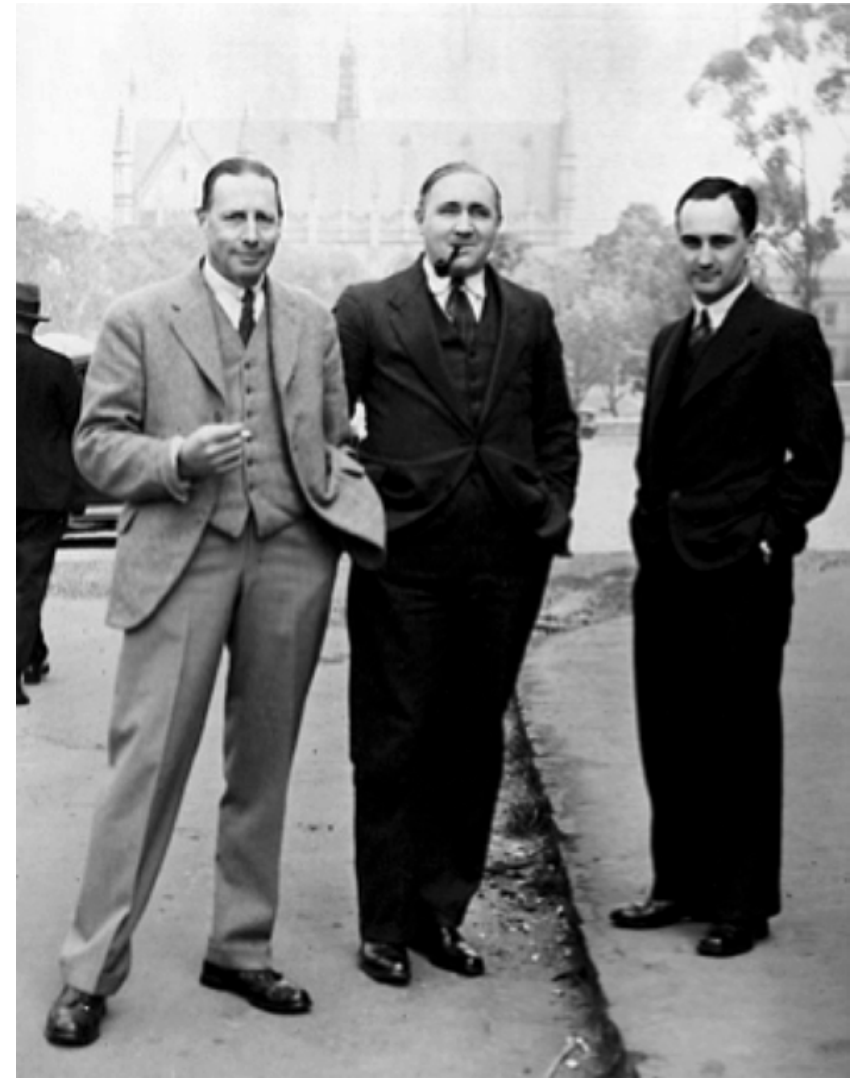

FIG. 3. Left to right: Professor Frederic Wood Jones, Sir Edward Fox, and Sir Sydney Sunderland, the staff of the University of Melbourne Medical School's Anatomy Department, 1936 (image courtesy of the State Library of Victoria, Melbourne).

with the majority of his papers focusing on the structure of human peripheral nerves, the pathophysiology of nerve injury and regeneration, and the natural history of anatomical and functional recovery following such injuries. His best-known contributions are his descriptions of the internal topography of peripheral nerves and his recognition that nerve fiber bundles that innervate specific muscles or sensory areas may vary in their relationships with one another at different levels within a nerve. The large body of work he produced is summarized in the 2 editions of an encyclopedia-like monograph-Nerve and Nerve Injuries $^{11,12}$ - which has been termed "the Bible" by Narakas, ${ }^{6}$ a pioneer of brachial plexus surgery; and in the book Nerve Injuries and Their Repair, ${ }^{13}$ published 2 years before his death. Both books are internationally acclaimed as classics. He also wrote 134 original scientific articles, most of them as either the first or only author. ${ }^{2}$

Sydney Sunderland was an active member of many federal government committees, including Australia's Health and Medical Research Council and its Medical Research Advisory Committee, the Advisory Medical Board of Australia, the Australian Universities Commission, the Protective Chemical Research Advisory Committee, the Safety Review Committee of the Australian Atomic Energy Commission, and the National Radiation Advisory Committee. He also held Australia accountable to its responsibilities for providing medical education to students

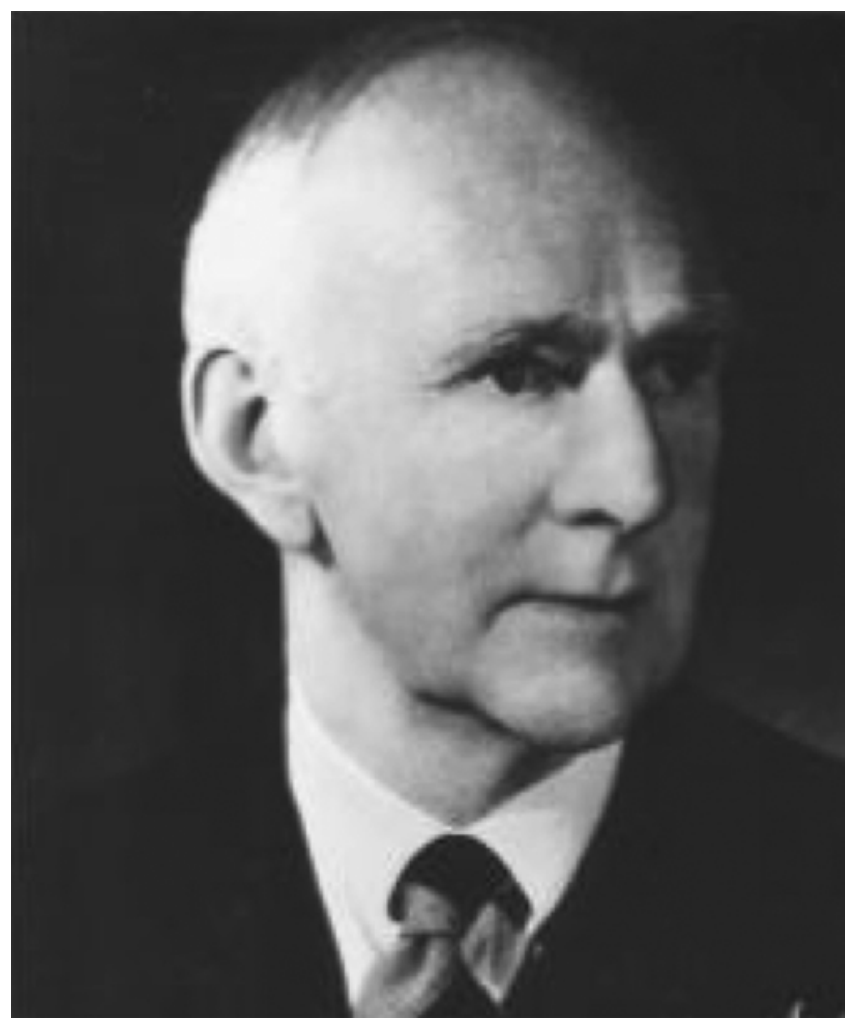

FIG. 4. Hugh Trumble (image courtesy of The Alfred Foundation).

from certain Asian nations, an effort that made him a popular invitee to Indonesia, Malaysia, Singapore, Burma (now called Myanmar), New Guinea, and Vietnam.?

His contributions to medical research, university administration, and governmental committees were recognized by the Governor General of the Commonwealth of Australia, who recommended that he be knighted by the Queen of England. In 1961, Sunderland was appointed as a Companion of the Order of Saint Michael and Saint George, and in 1971 he was made a Knight Bachelor. In the same year, he was honored with a portrait and plaque in the Medical History Museum of the University of Melbourne (Fig. 5). Sunderland was one of the 23 Foundation Fellows of the Australian Academy of Science in 1954, and played an important role in its early development. ${ }^{2} \mathrm{He}$ also was among the original governors of one of Australia's major philanthropic foundations - the Ian Potter Foundation (Fig. 6) - from the time of its inception in 1964 until his death. In 1994 this foundation established the annual Sunderland Award, which enables young neurobiologists to visit overseas laboratories (http://www.ianpotter.org.au/ who-we-are/our-heritage/).

In 1977, Sydney Sunderland received the title of honorary Doctor of Laws from Monash University (Fig. 7) (http://www.adm.monash.edu.au/records-archives/ archives/honorarygraduates/honorarygraduates-66-79. html). For many years he continued to support teaching and research in neuroscience at that university, and in 1991 he donated his complete personal library to the university, including a number of valuable first editions of classic neurological works (Andrew R: MON 720 Monash 


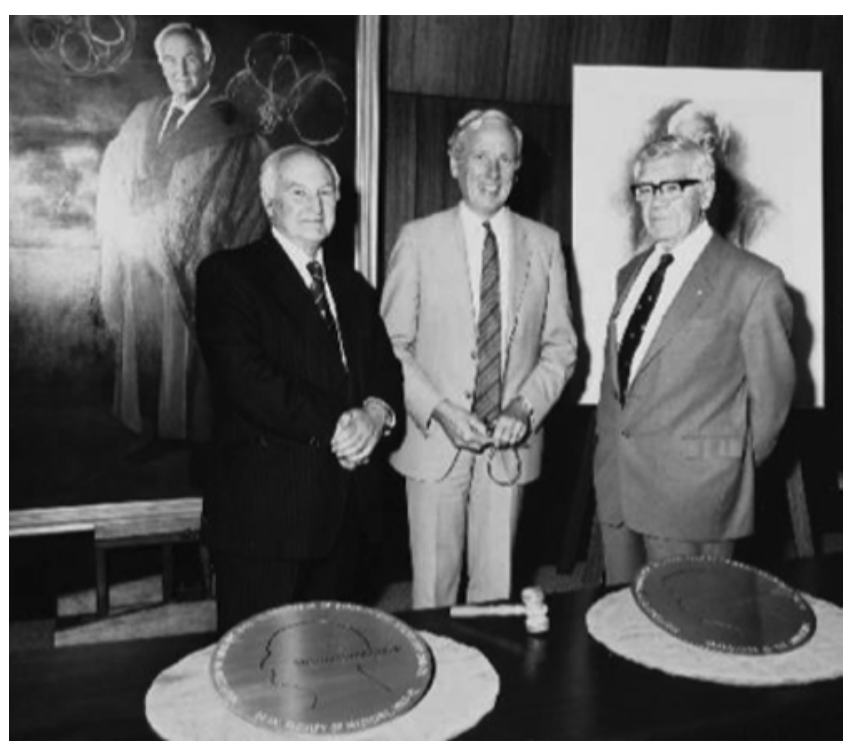

FIG. 5. Unveiling of the portraits and plaques honoring Sydney Sunderland and Roy Douglas Wright-Medical History Museum Collection/ University of Melbourne (David Penington stands in the center) (image courtesy of the Medical History Museum, University of Melbourne).

Faculty of Medicine, Faculty Board Minutes, Meeting 4/1993, Appendix F).

Sydney Sunderland was often referred to as "the father of modern nerve surgery," and the value of his work was recognized in a very public way when, in 1980, an international society dedicated to the study of peripheral nerve injury and repair was established and named the Sunderland Society in his honor. ${ }^{8}$

\section{The Sunderland Society}

In 1978, a group of surgeons interested in peripheral nerve pathology met at Duke University with Leonard

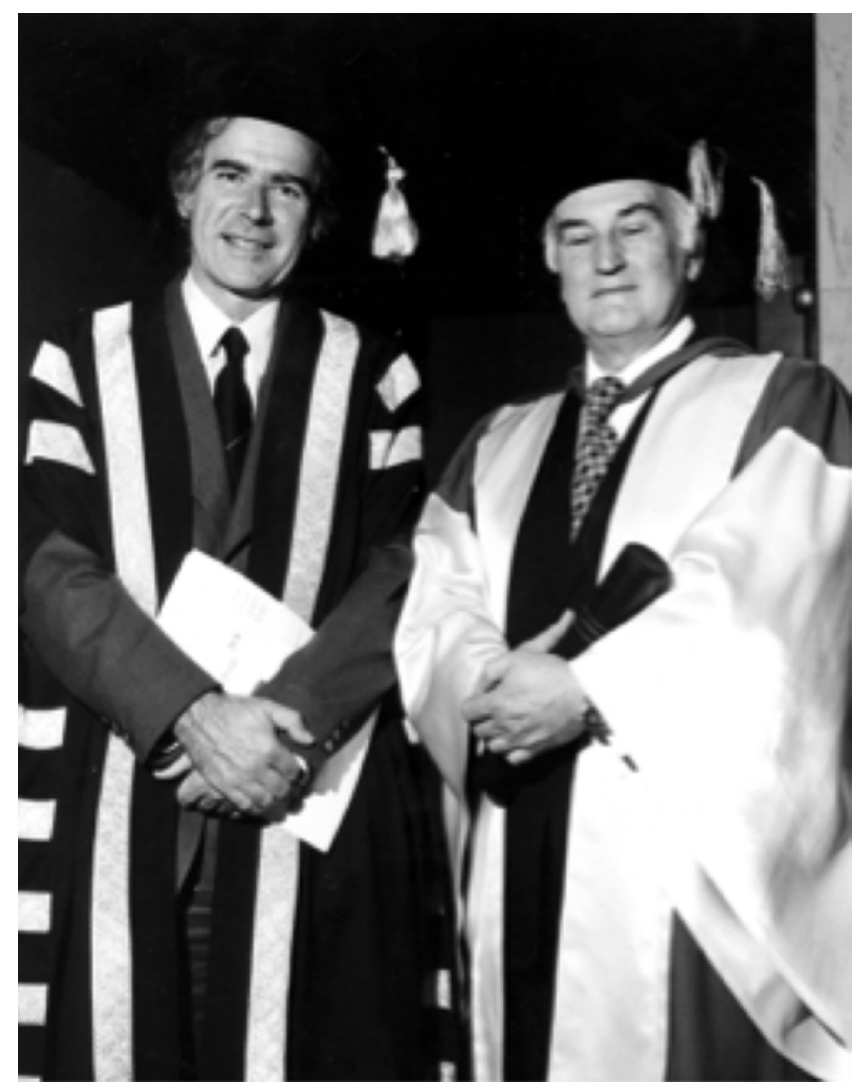

FIG. 7. Monash University honorary Doctor of Laws recipient Sir Sydney Sunderland (on the right) with Vice Chancellor Professor Ray Martin, 1977 (image courtesy of the Monash University Archives).

Goldner as host, to discuss the possibility of establishing a surgical peripheral nerve study group. It was agreed that clinicians and research scientists with a surgical interest in peripheral nerves should meet periodically to exchange their clinical experiences and assess recent advances in

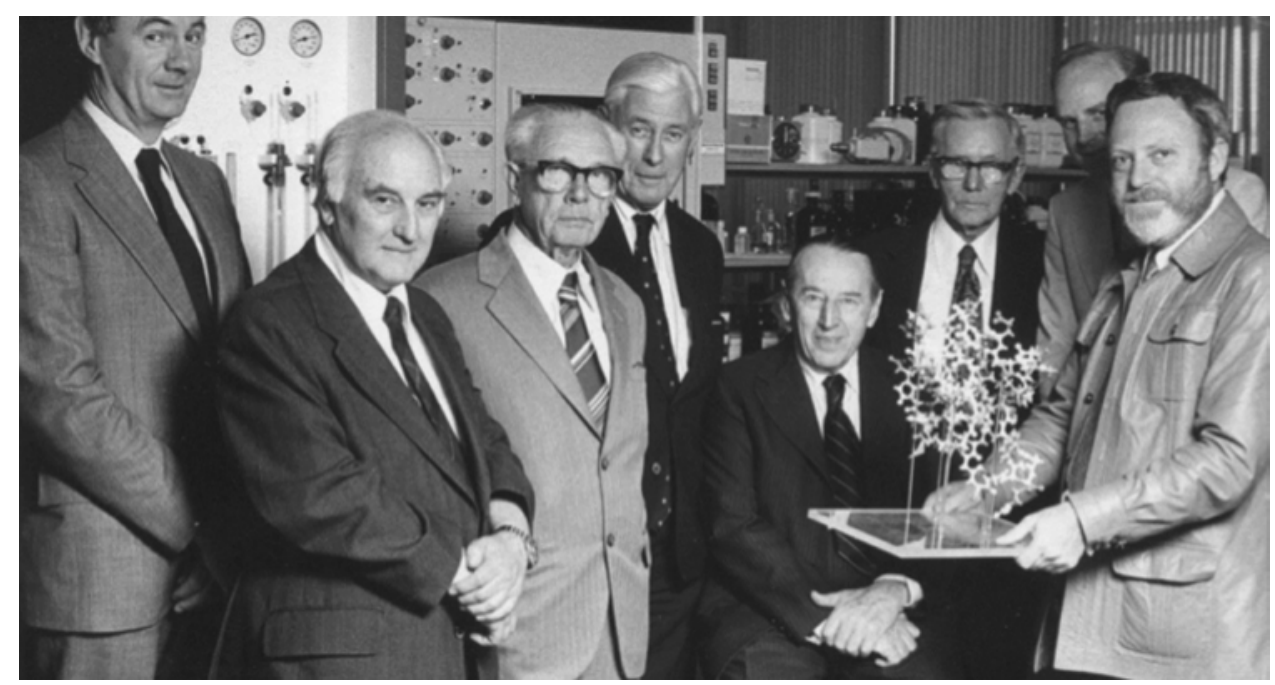

FIG. 6. Governors of the lan Potter Foundation at The Howard Florey Institute, circa 1979. Left to right: Dr. Thomas Hurley, Professor Sir Sydney Sunderland, Mr. Roy McArthur, Sir lan Potter, Sir Roger Darvall, and Sir lan Wark, with Florey Institute scientists Professors Geoff Tregear and Hugh Niall (image courtesy of the lan Potter Foundation). 


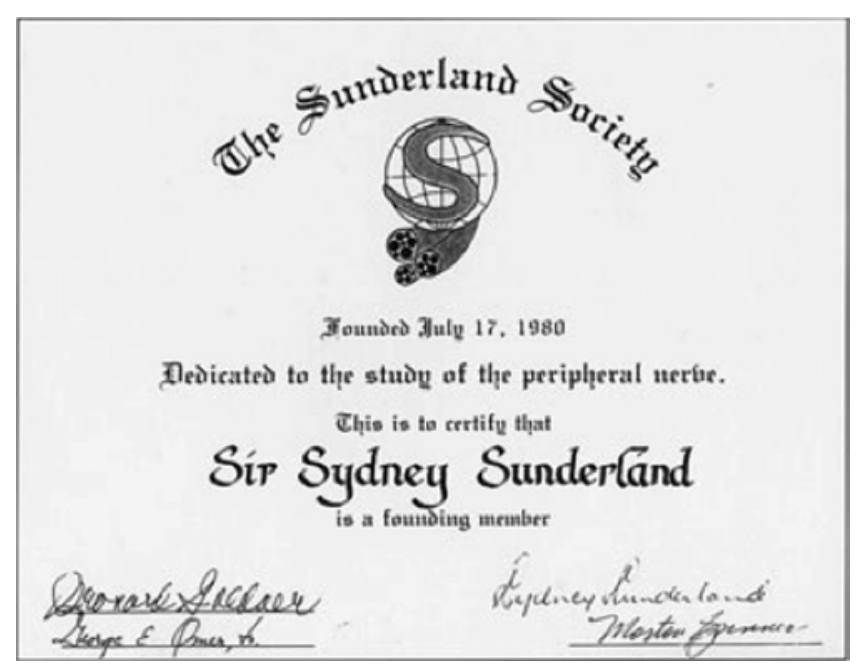

FIG. 8. Sunderland's certificate of membership in the Sunderland Society. Sir Sydney Sunderland collection, 1966.0035 (folder A0003, unit 1) (image courtesy of the University of Melbourne Archives).

research on peripheral nerves (see Kline DG: A history of the Sunderland Society: An international group for the study of peripheral nerves. Booklet of the XXII Sunderland Society Meeting, Ann Arbor, MI, 2015). A preliminary society was formed, with Raymond Curtis, Leonard Goldner, David Kline, George Omer, and Morton Spinner as the founding senior members. The concept was formalized in August 1979, during the midyear meeting of the American Society for Surgery of the Hand, and a "Peripheral Nerve Study Group" was founded with Raymond Curtis, Michael Jabaley, Joseph Kutz, George Omer, Morton Spinner, Jack Tupper, James Urbaniak, and Shaw Wilgis in attendance. Goldner and Kline were not present at that meeting but were aware of it. Morton Spinner was elected as the initial president of the group, and the first formal program was held on Long Island, New York, in July 1980. In recognition of Sir Sydney's considerable contribution to the field, he was invited to the meeting as a guest speaker. At this meeting, David Kline was selected as the next president, a meeting site in New Orleans was agreed upon, and an executive committee was created.

The membership quickly expanded to include several more members from the US, as well as from Australia, Canada, and Europe. In September 1980, David Kline proposed that the name of the group be changed because it was similar to The Neurological Nerve Study Group, and addressed mainly surgical issues rather than medical ones connected with nerves. The proposal was discussed by the executive committee and a new name was suggested-The Sunderland Society-a tribute to Sydney Sunderland's considerable contribution to the clinical study of nerve injury. The change was unanimously accepted by all its members, and Sir Sydney was delighted by this honor and unique tribute. The second formal meeting was held in New Orleans in November 1981, with David Kline as president. At the business meeting, the name of the group was officially changed from The Peripheral Nerve Study Group to The Sunderland Society. The third meeting was held in Santa Fe, New Mexico, in May 1983, with
TABLE 1. Sunderland Society meetings

\begin{tabular}{lll}
\hline Year & \multicolumn{1}{c}{ Site } & \multicolumn{1}{c}{ President } \\
\hline 1980 & Glen Cove, NY & Morton Spinner \\
\hline 1981 & New Orleans, LA & David Kline \\
\hline 1983 & Santa Fe, NM & George Omer, Jr \\
\hline 1984 & Baltimore, MD & Shaw Wilgis \\
\hline 1986 & Vienna, Austria & Hanno Millesi \\
\hline 1988 & Durham, NC & Leonard Goldner \\
\hline 1990 & Louisville, KY & Joseph Kutz \\
\hline 1992 & Malmo, Sweden & Goran Lundborg \\
\hline 1993 & Seattle, WA & Edward Almquist \\
\hline 1995 & Zurich, Switzerland & Victor Meyer \\
\hline 1997 & Vail, CO & Michael Jabaley \\
\hline 1999 & London, England & James Urbaniak \\
\hline 2001 & San Diego, CA & Richard Braun \\
\hline 2002 & Baltimore, MD & Thomas Brushart \\
\hline 2004 & Toronto, Canada & Rajiv Midha \\
\hline 2007 & Manchester, England & DA (Gus) McGrouther \\
\hline 2008 & Rochester, MN & Robert Spinner \\
\hline 2009 & Shanghai, China & Long-en Chen \\
\hline 2011 & New York, NY & David Chiu \\
\hline 2013 & Leiden, Holland & Martijn Malessy \\
\hline 2015 & Ann Arbor, Ml & John McGillicuddy \& Lynda Yang \\
\hline 2016 & Frankfurt, Germany & Kartik Krishnan \& Thomas Kretschmer \\
\hline & &
\end{tabular}

George Omer as president. There were 22 members from 6 countries, as well as several guests who attended. Sir Sydney was in attendance, and he subsequently attended every meeting until his death (Fig. 8). He was scheduled to present a paper titled "Thirteen years down the track" (referring to the 13 years that the Sunderland Society had been in existence) at the meeting to be held in Seattle in September of 1993, but he died in August of the same year. His paper was read posthumously at the Seattle meeting by the Sunderland Society president at that time, Edward Almquist, and by one of the original founders of the society, George Omer. This very thoughtful paper about the possible future of the field was subsequently published in the 2nd edition of Kline \& Hudson's Nerve Injuries..$^{15}$ In this paper, Sir Sydney posed 5 questions and then provided some discussion of each. Most if not all of his conclusions remain pertinent today. Since the founding of the Sunderland Society in 1980, there have been 22 memorable meetings (Table 1).

\section{Personal Life}

Sydney Sunderland was a generous man who was utterly devoid of self-promotion. His commitment to excellence was conveyed by example. Sir Syd, as he was affectionately known in the Department of Anatomy, married Nina Gwendoline in 1939; she was a lawyer who was a major supporter of his authorship and to whom he dedicated all his papers and monographs. Lady Sunderland committed much of her time to helping in the preparation of papers and monographs for publication, and to accompa- 
nying Sir Sydney to virtually all of the meetings in which he participated. ${ }^{5} \mathrm{He}$ always insisted that without her help and support throughout his career, his papers would not have been published. Their son, Ian Sydney Sunderland, graduated with a degree in medicine from the University of Melbourne, and became the investigating officer for the Medical Practitioners Board of Victoria. ${ }^{2}$

In the 1970s, David Kline invited Sir Sydney to visit Louisiana State University Health Sciences Center (LSUHSC) in New Orleans. Sir Sydney lectured on the Sunderland system and its 5 grades of injury, as well as on the importance of the anatomy of the nerve's fascicular system during nerve repair. As the lecture was concluding, Kline was called to the emergency room to see an acute nerve injury, and Sir Sydney elected to accompany him. The patient was a young man in his 20s who had been in a barroom fight earlier that afternoon. His left forearm was quite swollen and very bruised. He had a weak radial pulse and slightly delayed nail bed filling after compression. More striking were the findings of complete posterior interosseous nerve and superficial sensory radial palsy, as well as severe median palsy. Emergency room personnel recommended urgent fasciotomy. However, Sir Sydney thought that, in addition to the fasciotomy, both the radial nerve and its branches and the median nerve should be completely exposed and, if possible undergo neurolysis. He believed that, although both nerves undoubtedly had suffered neuropraxic injuries, they might also have been injured more directly. Kline followed this advice and found both nerves to be bruised but only slightly swollen while, of course, other soft tissues were very swollen and hemorrhagic at the mid-forearm level. Complete neurolysis was performed on both nerves at that level, in addition to more distal carpal tunnel release for the median. Recovery took several months. The radial nerve function returned first, ultimately achieving LSUHSC Grade 5, and median nerve recovery peaked at Grade 3-4 several months later.

Sunderland was a frequent and practical traveler. For international meetings he usually brought only 1 suit and, every night before the next day of seminars, he would wash and iron his underwear, socks, and shirt for wear the next day, and this routine persisted for as long as the meeting lasted.

Sir Sydney remained vibrant even in his later years. In 1983 he escaped unscathed after climbing up onto the roof of his coastal home to hose it down, along with the roofs of all his neighbors' homes, to save them and their inhabitants from the rapidly approaching Ash Wednesday bushfires. ${ }^{5}$ Survived by his wife and their son, he died of a disseminated lymphoma on Friday, August 27, 1993, in his 83 rd year, and was cremated. Typical of his lifelong modesty, he was adamant that there be no public memorial service following his death. ${ }^{8}$

There is virtually unanimous agreement among those in his field that Sir Sydney Sunderland was one of the greatest medical scientists of the past century. His death was mourned profoundly by the entire community of peripheral nerve clinicians and researchers. He will be remembered for the exceptional man that he was, and for the immense body of scientific work that he left behind.

\section{References}

1. Brown PW: Less than ten-surgeons with amputated fingers. J Hand Surg Am 7:31-37, 1982

2. Darian-Smith I: Sydney Sunderland (1910-1993). Hist Rec Aust Sci 11:51-56, 1996

3. Goodrich JT, Kliot M: History of the peripheral and cranial nerves, in Tubbs RS, Rizk E, Shoja MM, et al (eds): Nerve and Nerve Injuries. Amsterdam: Elsevier, 2015, Vol 1, pp 3-22

4. Guest JS: Trumble, Hugh Compson (1894-1962). Australian Dictionary of Biography. (http://adb.anu.edu.au/biography/ trumble-hugh-compson-11884) [Accessed September 21, 2017]

5. Jones RL: Sunderland, Sir Sydney (Syd) (1910-1993). Australian Dictionary of Biography. (http://adb.anu.edu.au/ biography/sundereland-sir-sydney-syd-26721/text34360) [Accessed September 21, 2017]

6. Narakas AO: In tribute-Professor Emeritus Sir Sydney Sunderland, KT(1971), C.M.G.(1961), M.D., B.S., D.Sc., Hon.LL.D.(Melb., Mon.), Hon.M.O.(Qld.,Tas.), F.R.A.C.P., F.R.A.C.S.(Hon.), F.A.A.-December 31st, 1910-August 27th, 1993. Microsurgery 15:163-164, 1994

7. Omer GE Jr: In memoriam-Sir Sydney Sunderland, KT, CMG, BM, Dsc, MD, FRACP, FAASc 1910-1993. J Hand Surg [Br] 19:159-160, 1994

8. Ryan GB: Obituary. Professor emeritus Sir Sydney Sunderland, Kt, CMG, MD, BS, DSc, HonLLD (Melb, Monash), Hon MD (Tas, Qld), FRACP, Hon FRACS, FAA. J Anat 187:249-251, 1995

9. Seddon HJ: Three types of nerve injury. Brain 66:237-288, 1943

10. Sunderland S: A classification of peripheral nerve injuries producing loss of function. Brain 74:491-516, 1951

11. Sunderland S: Nerves and Nerve Injuries. Edinburgh: Livingstone, 1968

12. Sunderland S: Nerves and Nerve Injuries, ed 2. Edinburgh: Churchill Livingstone, 1978

13. Sunderland S: Nerve Injuries and their Repair. A Critical Appraisal. Edinburgh: Churchill Livingstone, 1991

14. Sunderland S: Observations on the treatment of traumatic injuries of peripheral nerves. Br J Surg 35:36-42, 1947

15. Sunderland S: Thirteen years down the track, in Kim DH, Midha R, Murovic JA, et al (eds): Kline \& Hudson's Nerve Injuries: Operative Results for Major Nerve Injuries, Entrapments, and Tumors, ed 2. Philadelphia: Elsevier, 2008, pp 495-497

\section{Disclosures}

The authors report no conflict of interest concerning the materials or methods used in this study or the findings specified in this paper.

\section{Author Contributions}

Conception and design: Siqueira. Acquisition of data: Siqueira, Kline. Analysis and interpretation of data: Siqueira, Kline. Drafting the article: Siqueira. Critically revising the article: Kline. Reviewed submitted version of manuscript: Siqueira.

\section{Correspondence}

Mario G. Siqueira, Department of Neurosurgery, University of São Paulo Medical School, Rua Virgilio de Carvalho Pinto, 381/apt. 42, São Paulo 05415-030, Brazil. email: mgsiqueira@uol.com.br. 